\title{
Debatforum: \\ Hvordan erindres folkehøjskolens historie?
}

\author{
Af Ove Korsgaard
}

Ved en beklagelig redigeringsfejl havde enkelte delafsnit forrykket sig i lektor (i mellemtiden professor), dr. pæd. Ove Korsgaards debatindlæg "Hvordan erindres folkehøjskolens historie?" i Grundtvig-Studier 2006. Korsgaard har venligst gjort opmærksom på fejlen, og da fejlen kan virke meningsforstyrrende for læseren, skal den hermed berigtiges og indlægget genoptrykkes. Redaktionen for Grundtvig-Studier 2006 beklager fejlen.

Erindringshistorie er blevet et vigtigt felt inden for nyere historieforskning. Forskning i erindring viser, at det, vi erindrer om begivenheder i fortiden, kan ændre sig over tid. Erindringer er et felt, hvor der kan føres magtkampe om, hvad der skal huskes, og hvad der skal glemmes. Erindringspolitik betegner således en særlig form for identitetspolitik, hvor fortiden står i centrum i forsøg på at påvirke menneskers forestillingsverden, holdninger, værdier og følelser.

Historikeren Anette Warring fra RUC har gjort erindringspolitik til et vigtigt felt $\mathrm{i}$ sin forskning. Bogen Historie, magt og identitet (2004) handler om erindringspolitik med udgangspunkt i grundloven af 1849. Hun beskæftiger sig ikke med grundlovens indførelse som sådan, men med den måde grundlovens indførelse er blevet - og stadig bliver erindret og fortolket på. Analysen af en række grundlovstaler, holdt gennem de sidste 150 år, viser med stor tydelighed, at erindringen om grundlovens indførelse har ændret sig over tid.

Anette Warring indleder bogen med to citater fra henholdsvis statsminister Anders Fogh Rasmussens og tidligere statsminister Poul Nyrup Rasmussens grundlovstaler i 2002. Anders Fogh: "Vi fejrer i år grundlovens 153-års dag. I modsætning til andre lande fik Danmark sin frie forfatning i fred og fordragelighed." Poul Nyrup: "Vi fik vores grundlov på fredelig vis og ikke gennem blodige revolutioner. Netop det siger meget om os danskere. Vores evne til at tale om tingene. Vores evne til at samarbejde" (Warring 2004, 9). Men som Anette Warring viser, er det ikke altid, man har erindret grundlovens indførelse på den måde. I de første år havde man den borgerkrig, der fandt sted, da grundloven blev indført, for tæt inde på livet. Det var først efterhånden, det blev muligt at glemme og fortrænge borgerkrigen og fremstille grundlovens indførelse som en fredelig affære. Fortiden ændres, fordi fortolkningen af den er bundet til nutidige synsvinkler. 
Hvad med oprettelse af folkehøjskoler i Danmark? Hvordan er etableringen af denne skoleform blevet erindret tidligere? Og hvordan bliver den erindret i dag? På samme måde som Anette Warring har analyseret en række grundlovstaler, kan det gøres ved at analyse et udvalg af de højskoletaler, der har været holdt gennem de sidste 150 år. Det er ikke muligt i - og ej heller ambitionen med - denne artikel. I stedet vil jeg mere beskedent forholde mig kritisk til den form for rød tråd, der trækkes gennem højskolens historie ved at undersøge en række begrebspar som for eksempel dannelse og uddannelse, personlig udvikling og erhvervsfaglig undervisning. Tråden bruges til at placere højskolen i et kampfelt med en klar linje mellem 'ven' og 'fjende'. Højskolen skal beskæftige sig med dannelse, ikke uddannelse, med personlig udvikling, ikke erhvervsfaglig undervisning. Beskæftiger en højskole sig med indlæring af faglig færdighed, betragtes den som 'uren' og ikke en 'rigtig' højskole i klassisk forstand. Denne fortolkning af, hvad man skal forstå ved en folkehøjskole, er i dag lige så rodfæstet som erindringen om, at grundlovens indførelse var en yderst fredelig affære i Danmark.

Selv om det kan synes halsløs gerning at problematisere den skitserede måde at erindre højskolens historie på, vil jeg alligevel gøre et forsøg. Primært fordi højskolen har brug for en anden forståelse af sin egen fortid end den dominerende i nutiden.

\section{Folkehøjskolen som dannelsesskole}

Den streg, der i dag trækkes mellem dannelse og uddannelse, blev ikke trukket af højskolens fædre, blandt hvem Grundtvig med rette betragtes som stamfader. Også Grundtvig trak en streg, da han skitserede ideen om folkehøjskoler. Men den gik mellem to forskellige dannelsessyn, ikke mellem dannelse og uddannelse. Forenklet sagt var spørgsmålet, om det var nødvendigt at lære latin for at blive et dannet menneske i Danmark, eller om man kunne blive det ved hjælp af det sprog, som 'folket' talte, nemlig dansk. Da Grundtvig kom frem til den opfattelse, at dansk var et fuldgyldigt dannelsessprog, gik han til frontalt angreb på såvel den klassiske som den nyhumanistiske dannelsestradition, der betragtede henholdsvis latin og græsk som forudsætning for dannelse. Det førte Grundtvig ud i et stort opgør med kultusminister Madvig.

Madvig' og Grundtvig var som henholdsvis nyhumanist og (en slags) nationalromantiker enige om mange ting, især at dannelsen til menneske må funderes på sprog, litteratur og historie. Derfor forholdt de sig begge kritisk til filantropernes mere nyttebetonede skole- og opdragelsessyn. I en artikelserie om den lærde skoles undervisning 
kritiserede Madvig i begyndelsen af 1830 'erne de filantropisk inspirerede skoler for at fremhæve "Realiteternes Fortrin i Undervisningen og ved Realiteterne igjen især at forstaae Naturhistorie". Disse skoler manglede sans for "Vækkelse af det høiere i Mennesket" (Madvig 1833, 270 f.). Madvig afviste skarpt den filantropiske målsætning: "at danne nyttige Mennesker". Dannelsens mål var den "høiere Menneskelighed" og det "høiere Liv" (Madvig 1832, 8 f.). Det samme kunne Grundtvig have sagt.

Alligevel kom Madvig og Grundtvig til at stå som markante poler i synet på dannelse - og på begrebet højskole. Det var lykkedes Grundtvig at få Christian VIII til kort før sin død i januar 1848 at udsende en resolution om oprettelsen af en "Realhøjskole" i Sorø. Denne plan var imidlertid blevet stillet i bero af D. G. Monrad, der blev kultusminister i marts 1848. I november 1848 afløste Madvig Monrad som minister; samtidig var Grundtvig - efter omvalg i Præstø Amt - blevet indvalgt i Den Grundlovgivende Rigsforsamling. Som sin første handling i Rigsdagen rettede Grundtvig i december 1848 en forespørgsel til den ansvarlige kultusminister om Sorø Akademis fremtid.

Grundtvig indleder sin forespørgsel med at sige:

Jeg er nu en gammel, afgjort selvstændig Mand, som ikke kan høre til noget af Døgnets politiske Partier, og jeg er ene kommet her paa Rigsdagen for med gammel dansk Jævnhed og Dristighed at tale Frihedens, Folkelighedens og Oplysningens Sag.

Dog ikke oplysning i al almindelighed, men dansk oplysning som forudsætning for en "folkelig Igjenfødelse". I de eksisterende "latinske" institutioner var der ikke muligheder for at få den oplysning om "Fædrelandet og hvad dansk" var, som der netop nu var så hårdt brug for. Folkehøjskolen skulle være for alle klasser, og her skulle "Folkets Stemme" høres (Rigsdagstidende 1848, 433 f.).

Madvig lod ikke denne lejlighed til at forholde sig kritisk til Grundtvigs dannelsestanker gå fra sig. Han indledte blødt med at sige, at spørgsmålet om Sorø var behandlet alt for isoleret og alt for ensidigt. "Det maa nødvendigviis behandles i Sammenhæng med Spørgsmaalet om hele det høiere Underviisningsvæsens Indretning i Danmark." Derefter tog han fat på Grundtvigs påstand, at de eksisterende skoler og universitetet ikke var "danske". Denne påstand fandt han absurd. "De Skoler, som man før har kaldet Latinskoler, ere danske og skulle være det; Universitetet her i Kjøbenhavn er dansk og skal være det." Madvig ville ikke være med til at oprette en skole, der tog monopol på "Danskheden". Og han gav Grundtvigs Sorø-plan dødsstødet med de siden så berygtede og ofte citerede ord: "Der skal ikke være, og jeg tænker heller ikke paa at foreslaae noget Saadant, en særskilt, Charakteren af Danskhed monopoliserende Underviisnings- 
anstalt" (Rigsdagstidende 1848, 436). Hvis der endelig skulle være ét sted, der skulle kaldes en skole for danskheden, så måtte det være den rigsdagssal, hvori de netop stod.

Madvig fulgte dette frontalangreb op med en kritik af Grundtvigs brug af begrebet højskole, som i den gængse sprogbrug betød en højere læreranstalt eller et universitet. Madvig mente ikke, at Grundtvig med nogen ret kunne anvende begrebet højskole for en skole, der skulle være tilgængelig for elever uden forkundskaber - ud over den folke- og almuedannelse, de havde fået $\mathrm{i}$ almueskolen. Enten ville eleverne ikke fatte noget af det, der foregik, eller også ville man skulle sænke niveauet, så det ikke længere kunne kaldes en højskole. Mens Madvig var yderst kontant i sin afvisning af Grundtvigs Sorøplan, forholdt han sig positivt til idéen om oprettelse af "høiere Bondeskoler", der på linje med de allerede eksisterende "høiere Borgerskoler" kunne lede frem til den eneste egentlige "Højskole", nemlig universitetet i København. På dette højere niveau "bør Modsætningen mellem Borger og Bonde falde bort" (Rigsdagstidende 1848, 439).

Grundtvigs replik til Madvig var besk. I Danskeren nr. 401848 betegnede han deres diskussion som den første dyst mellem "Dansken og Latinen" på Rigsdagen (Grundtvig 1848, 471). Grundtvig, der omtalte sig selv som "den gamle Dansker", skrev bittert, at man fra "den grundmurede Latiner" ikke havde kunnet vente andet svar. Og han fandt det utroligt, at en "stiv Latiner noget Øieblik kan være Minister for Danmarks Kirke- og Skole-Væsen" (Grundtvig 1848, 477). Men Grundtvig var fortrøstningsfuld. Hvad der kom til at ligne en "Tvekamp mellem den magthavende Latiner og en stakkels overseet Dansker", var i virkeligheden "en Forpost-Fægtning mellem Danskheden i sit Hjem og Latineriet i Flugten" (Grundtvig 1848, 473).

Madvig blev drivkraften i den uddannelsesreform, som lå de nationalliberale mest på sinde, nemlig reformen af de lærde skoler $\mathrm{i}$ Danmark. Arbejdet på en lovreform var allerede sat i gang i efteråret 1848. Madvig kom som kultusminister til at præge den endelige lov $\mathrm{i}$ en sådan grad, at den meget passende er blevet kaldt den 'madvigske skoleordning'. I lov af 13. maj 1850 fik det lærde skolevæsen som formål at give en undervisning, "der kan føre til en sand og grundig almindelig dannelse" og forberede eleverne til "det akademiske studium af de videnskaber og fag, til hvilke den enkelte føler kald" (Haue 1986, 132). Hverken før eller siden har nogen med samme konsekvens som Madvig gjort dannelse til skolens hovedopgave. For ham gik dannelse til menneske forud for enhver faglig betinget specialisering. 
Men i 1871 måtte Madvig acceptere en todeling af den lærde skole i en "sproglig-historisk" og en "matematisk-naturvidenskabelig" linje. Som landstingsmedlem stemte han uden entusiasme for planen:

Jeg vilde fastholde Skolens Enhed, hvis vi havde (...) en fri Skole for almindelig Dannelse, der kun søgtes af dem, der havde en indre Trang og ydre Vilkaar til at modtage Dannelsen i den fuldstændigste og bedste Skikkelse uden Hensyn til deres fremtidige Livsstilling (Rigsdagstidende 1870/71, 2750).

Madvig er i langt højere grad end Grundtvig fortaler for en 'ren' dannelsesskole.

Når Madvig endte med at tilslutte sig forslaget om en todeling af latinskolen, var det for at undgå noget værre, nemlig oprettelse af en oldnordisk linje, som grundtvigianerne på det tidspunkt krævede. For Madvig var det en vederstyggelig idé, som han i Landstinget gav en hård medfart. I den udstrækning danskerne ville være et dannet folk, måtte de studere Europas historie og ikke udviklingen på Island. Det ville være en dannelsesmæssig ulykke, hvis den nordiske kultur blev vigtigere end den europæiske:

Hvis vi ville hævde vort nordiske Liv, saa lader os hævde det som Medlemmer af den europæiske Folkeslægt, og lader os hævde det paa det Grundlag, der ene kan bære en Uddannelse, der stiller os mellem de europæiske Folk (Rigsdagstidende 1870/71:2754 f.).

For Madvig var det altafgørende at fastholde forbindelsen mellem det nationale og det universelle, mellem det danske og det europæiske.

Mens Madvig med næb og klør kæmpede for at fastholde almen dannelse som ledetråd for undervisningen i gymnasieskolen, skelnede Grundtvig i sine højskoleskrifter mellem dansk dannelse og latinsk dannelse, ikke mellem dannelse og uddannelse. Nok havde dansk dannelse det danske sprog som forudsætning, men ikke det danske erhvervsliv som modsætning. Tværtimod. I sit sidste store højskoleskrift Lykønskning til Danmark med Det Danske Dummerhoved og Den Danske Høiskole fra 1847 skriver han for eksempel:

At man ved Siden ad den Danske Høiskole drev en Avlsgaard udmaerket godt, det vilde vistnok baade være fornøieligt og gavnligt, og hvis Høiskolen var omringet af Varksteder, hvor alle Haandvaerker dreves udmærket godt, da vilde baade Fornøielsen og Gavnligheden være udmarket stor (Grundtvig 1847, 254).

Højskolen skulle imidlertid ikke kun være 'omringet' af værksteder, undervisningen skulle også omfattede emner som for eksempel Danmarks naringsveje og hjolpekilder. ${ }^{2}$

Der er ingen tvivl om, at det er kampen mellem 'latinsk' og 'dansk-nordisk' dannelse, der for Grundtvig nødvendiggør en dansk 
folkehøjskole. At få dansk anerkendt som dannelsessprog gav mulighed for, at ikke kun 'eliten' kunne blive dannede mennesker, men også 'folket'. Det var ikke kun sproget, der skilte i denne dannelseskamp, det samme gjorde opfattelsen af kultur i bredere forstand. Det kommer for eksempel til udtryk i et replikskifte mellem biskop Martensen, København, og forstander Ernst Trier, Vallekilde: "Er det virkelig Deres mening, kære Trier, at De vil gøre æstetisk dannede mennesker ud af disse karle og piger?" Nej, det ville Trier ikke:

Det jeg vil give eleverne del i, er ikke den æstetiske dannelse, men en virkelig poetisk opfattelse af livet. Ikke den, der giver fordringer til livet, så de ikke kan malke en ko, fordi lugten i stalden svækker livsnydelsen, men den dannelse, der giver glæde $\mathrm{i}$ arbejdet (Thomsen 1982, 46).

Ernst Triers bestræbelse var at fremme vekselvirkningen mellem åndsliv og produktionsliv, mellem myter og mønter, dannelse og uddannelse.

Grundtvigs vision om en højskole 'omringet' af værksteder udgjorde modellen for Ernst Triers opbygning af Vallekilde Højskole. Gennem flere årtier eksisterede der forskellige afdelinger på højskolen, en håndværkerafdeling, en malerafdeling, en søfarts- og fiskeriafdeling, samt - selvfølgelig - en avlsgård. Trier deltog selv aktivt i landbruget og fungerede som en slags forsøgsleder. På søfarts- og fiskeriafdelingen blev der om formiddagen undervist i fag som gymnastik (sammen med håndværkerne), Danmarks natur- og folkeliv, husflid, retskrivning, fiskeriloven og vedtægter; om eftermiddagen fik fiskerne undervisning $\mathrm{i}$ almindelig regning, beregning af skibets position på havet samt forberedelse til fiskeri-eksamen. Sidste på eftermiddagen samledes eleverne fra de forskellige afdelinger til fælles foredrag om Danmarks historie (Walstad 2006, 172 f.).

\section{Højskolen som uddannelsesinstitution}

Selv om Grundtvig og Trier ikke skelnede skarpt mellem dannelse og uddannelse, meldte forholdet mellem de to dimensioner sig som problemstilling i folkehøjskolen straks fra starten. På Rødding Højskole opstod der få år efter åbningen i 1844 en strid om, hvorvidt folkelig-national dannelse eller landbrugsfaglig uddannelse skulle have første prioritet. Selv om Edv. Thomsen, der var naturfagslærer og landbrugslærer, led nederlag i denne strid, forblev landbrugsundervisningen en del af programmet (Korsgaard 1997). Dermed blev Rødding model for tilrettelæggelse af undervisningens indhold på højskolerne. Det normale blev, at man satsede på at kombinere to ting. Det ene var at give de unge en folkelig-national dannelse, der gav 
mulighed for at blive en integreret del af det danske folk, det andet var at give en landbrugsfaglig uddannelse, der satte dem i stand til at forbedre driftsforholdene i landbruget. Det arketypiske eksempel på dette samspil mellem dannelse og uddannelse er det første efterårsmøde på Askov Højskole i 1865, hvor der blev holdt tre foredrag: ét om nordisk mytologi, ét om det sønderjyske spørgsmål og ét om spat hos heste.

Folkehøjskolen blev oprettet på et tidspunkt i den danske skoles udvikling, hvor en stigende del af ungdommen begyndte at efterspørge undervisning ud over de 7 år i almueskolen. For de fleste unge på landet var nogle måneder på en højskole eneste mulighed for at få mere undervisning, end de havde fået i almueskolen. De unge tog ikke på højskole for at prøve noget andet end 'den sorte skole'. Den fik så godt som ingen af dem berøring med, idet kun få procent af en ungdomsårgang gik i den lærde skole. De tog på højskole for at opleve noget og lære noget. For de fleste elever indgik et højskoleophold i såvel et dannelses- som et uddannelsesperspektiv.

Højskolens uddannelsesmæssige funktion har aldrig været gjort til genstand for systematisk undersøgelse. En sådan er der et stort behov for. Her skal kun nævnes spredte eksempler på højskolernes uddannelsestilbud. Gennem 125 år underviste alle højskoler i fag som skrivning og regning; og næsten alle havde landbrugsfaglig undervisning, alene omfanget varierede. På landet manglede der imidlertid ikke kun uddannelsesmuligheder for vordende landmænd, men også for landhåndværkere. Det førte til oprettelse af en række håndværkerafdelinger. I 1904-05 fandtes der sådanne afdelinger på en tredjedel af alle højskoler. På Vallekilde Højskole var håndværkerafdelingen på et tidspunkt den største afdeling på højskolen.

Som eksempel på højskolens uddannelsesmæssige betydning kan også nævnes, at i 1901 startede Askov Højskole elektricitetskurser for møllere og mejerister. Fra 1904 til 1918 blev der på forsøgsmøllen på Askov Højskole afholdt tre måneders kurser, hvor elektrikere fik en uddannelse som en slags landlige installatører. Her underviste den daværende forstander Jacob Appel i kemi og fysik og den senere forstander J. Th. Arnfred i elektroteknik, maskinlære, mekanisk fysik, matematik og regning.

Folkehøjskolens erhvervsfaglige og studieforberedende undervisning har haft varierende indhold og omfang gennem historien. Men i takt med at landhåndværkerne blev stillet over for de samme uddannelsesmæssige krav som byhåndværkerne, blev de stærke bånd mellem folkehøjskolen og landhåndværkerne sprængt i mellemkrigstiden. I perioden 1920-40 blev håndværkerundervisningen udskilt fra højskolerne i selvstændige håndværkerskoler, som for eksempel i Haslev 
og Ollerup. I 1936 blev håndværkerafdelingen nedlagt på Vallekilde Højskole. Den landbrugsfaglige undervisning fortsatte derimod frem til 1968. Mens folkehøjskolens og den faglige håndværkerundervisnings veje endelig skiltes omkring 1940, skete det samme først med den landbrugsfaglige undervisning omkring 1970.

I samme periode blev en række 'forskoler' på højskoler nedlagt, for eksempel forskoler for sygeplejersker og forskoler for seminarier (præparandklasser). Den forskole for sygeplejersker, der i 1927 var blevet oprettet på Testrup Højskole, blev således nedlagt i 1975. Med indførelse af HF (Højere Forberedelseseksamen) blev de forskoler til seminarier, der fandtes på flere højskoler, ligeledes nedlagt. Disse forskoler havde fungeret på den måde, at den prøveforberedende undervisning fandt sted på højskolerne, hvorimod selve optagelsesprøven blev afholdt på et seminarium.

Såvel den erhvervsfaglige som studieforberedende undervisning gik således endeligt $\mathrm{i}$ opløsning omkring 1970. Den form for undervisning blev overtaget af nye uddannelsesinstitutioner som for eksempel HF, VUC (Voksenuddannelsescenter) og AMU (Arbejdsmarkedsuddannelse). Fra at de private højskoler gennem årtier havde været eneste mulighed for 'opkvalificering', blev folkehøjskolen nu i stigende grad 'omringet' af offentlige uddannelsesinstitutioner, der hver tog deres del af den kompetencegivende undervisning, der tidligere havde fundet sted på højskoler. Dog er der den afgørende forskel, at på de nye offentlige uddannelsesinstitutioner får man formel kompetence efter bestået eksamen.

Folkehøjskolens nye kontekst kan perspektiveres ved kort at inddrage efterskolen, der omkring 1960 for alvor blev konfronteret med det problem, at flere og flere unge begyndte at tage et 8 . og 9 . skoleår $\mathrm{i}$ folkeskolen og derfor ikke længere var potentielle efterskoleelever. Spørgsmålet var derfor, om de private, selvejende efterskoler skulle fastholdes som 'ren' efterskole, det vil sige 5 måneders vinterskole for drenge og 3 måneders sommerskole for piger - uden prøver. Eller om efterskolerne skulle tilbyde 8. og 9. klasse med prøver. Selv om formanden var imod og sagde: "det bliver over mit lig", gik et flertal i bestyrelsen ind for prøveforberedende undervisning. Hvis ikke efterskolen havde ændret kurs, ville skoleformen sikkert være ophørt med at eksistere. Kursskiftet gjorde det muligt for efterskolen at udvikle sig til den mest succesfulde skoleform i Danmark gennem de sidste 30 år.

For folkehøjskolen var spørgsmålet: Skulle det være muligt at tage HF eller HF-enkeltfag på højskoler? Helge Severinsen, forstander på Skælskør Folkehøjskole, var i begyndelsen af 1970'erne en varm fortalerne for det synspunkt. Men forslaget vandt ikke tilslutning i 
højskoleforeningens bestyrelse. K. E. Larsen, der var formand for højskoleforeningen på det tidspunkt, var imod, hvilket han senere fortrød (Korsgaard 1997a). ${ }^{3}$ Når HF blev afvist, hang det blandt andet sammen med, at to års undervisning ikke lod sig indpasse $\mathrm{i}$ den struktur, som kendetegner den danske folkehøjskole.

Med tabet af de omtalte uddannelsesopgaver og med beslutningen om at sige nej til HF blev der for alvor åbnet for en fortolkning af højskolens historie, der gjorde en skelnen mellem dannelse og uddannelse til højskolens særkende. At forstå højskolens idé og historie ved hjælp af stregen mellem dannelse og uddannelse kan som tendens spores langt tilbage i højskolens historie. Men det er først gennem de sidste tre-fire årtier, at denne streg erindres som det historiske udgangspunkt for højskolen.

\section{Den 'urene' højskole}

Min konklusion er ikke, at uddannelsesdimensionen har udgjort den primære drivkraft, og at dannelsesdimensionen kun har haft minimal betydning for motiverne til at tage på højskole. Min konklusion er derimod, at begge dimensioner har spillet en rolle siden oprettelsen af den første højskole. De fleste højskolefolk har gennem mere end hundrede år fastholdt en klar rangorden mellem fag, der blev betragtet som værende af vital betydning for de unges dannelse, og fag med et mere instrumentalt sigte. Men de har også erfaret, at skulle højskolens dannelsesmæssige hovedsigte fastholdes, skulle der brød på bordet. Og det fik man blandt andet ved at tilbyde de unge erhvervsfaglig og prøveforberedende undervisning af forskellig slags. Som private skoler kunne højskoleforstandere ikke uden stor økonomisk risiko se bort fra dette behov. Det var først omkring 1970, at man kunne tillade sig den luksus.

Ingen har klarere end forstander Ludvig Schrøder, Askov Højskole, peget på de markedsmæssige vilkår, som højskolen altid har været underlagt. Ifølge Schrøder skal en højskoleforstander selvfølgelig lytte til gode råd om højskolens opgaver fra velmenende mennesker,

men han kan ikke forpligte sig til at følge den givne anvisning; 'ideen' kan være nok så smuk: når den ikke passer ind i den hårde virkelighed, så kan han ikke bruge den; bliver hans skole tom (...), da kommer han til at sulte, og det er da kun en ringe trøst, at det er for ideens skyld han sulter (Schrøder 1872, 454).

Schrøder sammenfatter sine synspunkter i de så ofte citerede ord:

Der, hvor folkets trang, som kan være forskjellig paa forskjellige steder og til forskjellige tider, møder lærernes ævne, der ligger 
højskolens gjerning. Derfor kan folkehøjskolen, saa længe den er en fri, af staten uafhængig, skole, aldrig blive en fast indretning, som gaar efter bestemte regler; altid vil den blive afhængig af deres ævner, som vil virke paa ungdommen, og af denne trang (Schrøder 1944, 80).

Højskolen blev ikke etableret ved, at man for 150 år siden slog en streg mellem dannelse og uddannelse. Den blev etableret for at erstatte én form for dannelse med en anden form. At højskolen blev skabt som dannelsesskole betød, at der blev indført et hierarkisk forhold mellem dannelse og uddannelse, men det betød ikke, at højskolen distancerede sig fra uddannelsesmæssige opgaver.

Graver man bare lidt i historien, vælder det frem med erhvervsfaglig og studieforberedende undervisning af forskellig art. Måske forholder det sig i virkeligheden sådan, at folkehøjskolen aldrig ville have opnået den store succes og betydning, som skoleformen vitterlig opnåede, uden at imødekomme landbefolkningens behov for efter- og videreuddannelse. Men da denne side af historien ikke passer ind i forestillingen om 'den rene højskole', har der været en stærk tendens til at fortrænge og glemme denne del af historien. Det er ikke den, der fortælles ved festlige lejligheder. At en vigtig del af højskolens historie er gledet ud af erindringen, kan have fatale konsekvenser. Ved at fastfryse højskolens fortid i billedet af 'den rene højskole', blokerer man for en nuanceret diskussion om højskolens fremtid. For måske er det netop $\mathrm{i}$ den fortrængte og glemte side af højskolens historie, der i dag kan hentes inspiration til at bringe højskolen ud af den strukturelle og idémæssige krise, den befinder sig i.

Konklusion: Højskolens fremtid afhænger af en anden forståelse af dens fortid end den i nutiden dominerende.

\section{Forkortelser}

HF: Højere Forberedelseseksamen

RUC: Roskilde Universitetscenter

VUC: Voksenuddannelsescenter

AMU: Arbejdsmarkedsuddannelse

\section{Litteraturliste}

\section{Værker af Grundtvig}

Grundtvig, N. F. S. (1847), "Lykønskning til Danmark med Det Danske Dummerhoved og Den Danske Høiskole" i K. E. Bugge (udg.) (1968), Grundtvigs skoleverden i tekster og udkast, bd. 2, 210-267. 
(1848), "Den danske Høiskole, den latinske Minister og Rigsdagsmanden fra Præstø" i Georg Christensen \& Hal Koch (udg.) (1943), N. F. S. Grundtvigs Varker i Udvalg, bd. 4, 471480 .

\section{Værker af andre forfattere}

Haue, Harry m.fl. (1986): Skolen i Danmark: fra 1500-tallet til i dag, København.

Korsgaard, Ove (1997), Kampen om lyset. Dansk voksenoplysning

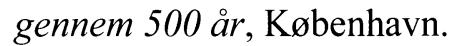

(1997a), "Samtaler med tidligere undervisningsdirektør K. E. Larsen" i Uddannelseshistorie, København.

Madvig, J. N. (1832-33), "Om den lærde Skoleunderviisning" i Maanedsskrift for Litteratur, København.

Thomsen, Mette (1982), Kunsten og folkehøjskolen, København.

Beretninger om Forhandlinger i Rigsdagen (1848), København.

Rigsdagstidende (1870-71), København.

Schrøder, Ludvig (1872), "Nogle bemærkninger om folkehøjskolemødet i Kristiania" i Nordisk Månedsskrift for folkelig og kristelig oplysning, Kristiania.

__ (1944), "Folkehøjskolemødet i Kristiania" i Valdemar Stenkilde (red.), Den grundtvigske Folkehøjskole belyst ved Højskolemøends Artikler og Taler 1844-1944, København.

Walstad, Pål Henning Bødtker (2006), Dannelse og Duelighed for Livet, Trondheim.

Warring, Anette (2004), Historie, magt og identitet, Århus.

\section{Noter}

1 Johan Nicolai Madvig (1804-86); cand.mag. 1825; professor i filologi 1829-79; kultusminister 1848-51; undervisningsinspektør for de lærde skoler 1848-74; medlem af Folketinget 1849-53; medlem af Landstinget 1853-74.

2 Pål Walstad har i sin ph.d.-afhandling Dannelse og Duelighed for Livet (2006) fremdraget en række eksempler på den betydning, som Grundtvig tillagde erhvervsfaglig undervisning og praktisk arbejde i højskolen.

3 I et interview med Ove Korsgaard, hvoraf uddrag er bragt i: "Samtale med tidl. undervisningsdirektør K. E. Larsen” (Korsgaard 1997a). 